\title{
Pengaruh Kesesuaian Dan Kesatuan Terhadap Minat Pembelian Rolex Dalam Game F1 Mobile Racing Pada Mahasiswa Untar Dan Pengunjung Mall Ciputra Di Jakarta
}

\author{
Giovanni dan Carunia \\ Program Studi Manajemen, Fakultas Ekonomii dan Bisnis \\ Universitas Tarumanagara, Jakarta \\ Email: harifingiovanni@yahoo.com
}

\begin{abstract}
The purpose of this research is to obtain empirical evidence on the influence of congruity and integration of purchase intention on Rolex advertising brands in F1 mobile racing games. The study used 30 samples that had been selected (the sample realized the presence of Rolex in-game advertising) for a total of 30 respondents. Processing and testing this data using SmartPLS 3. The results of this research show that congruity and integration has no positive effect on purchase intention.
\end{abstract}

\section{Keywords: Congruity, Integration, Purchase Intention}

Abstrak: Tujuan penelitian ini adalah untuk memperoleh bukti empiris mengenai pengaruh kecocokan dan integrasi terhadap minat pembelian merek iklan Rolex di game f1 mobile racing. Penelitian ini menggunakan 30 sampel yang telah diseleksi (sampel tersebut menyadari adanya iklan Rolex dalam permainan) dengan total 30 responden. Pengolahan dan pengujian data ini dengan menggunakan SmartPLS 3. Hasil penelitian ini menunjukkan bahwa kecocokan dan integrasi tidak berpengaruh positif terhadap minat pembelian

Kata Kunci: kecocokan, integrasi, minat pembelian

\section{LATAR BELAKANG}

Game sudah menjadi hal umum bagi semua kalangan penduduk di Indonesia. Banyak anak kecil, remaja, maupun dewasa yang menjadikan game untuk mengisi waktu luang mereka. Pada era sekarang ini game bisa dimainkan di smartphone dan sudah banyak sekali game dengan grafik yang bagus walaupun hanya dengan smartphone yang umumnya berlayar kecil. Seiring dengan perkembangan game online, sudah banyak perusahaan game online yang mencoba membuat game di dalam smartphone. Data menunjukan aktivitas yang dilakukan masyarakat untuk bermain game adalah sebesar $25 \%$, dimana aktivitas untuk bermain game merupakan yang tertinggi diantara jenis aktivitas yang lainnya (Maulida, 2018).

Dari waktu ke waktu banyak game yang perlahan mulai mencoba teknik dalam memasarkan produk yang berupa barang / jasa. Salah satu teknik itu bernama In-game advertising. In- game advertising adalah penempatan merek (product placement) dalam game, biasanya dalam bentuk Billboard, poster, atau sponsor Signage dalam olahraga dan game balap (Yang et al., 2006). Selain penjualan permainan, meningkatnya jumlah pengguna permainan membuat video dan permainan ponsel pintar menjadi cara yang menarik untuk 
penempatan merek, hal ini menyebabkan timbulnya pengaruh minat beli konsumen game di indonesia.

In - Game Adertising (IGA) dibagi menjadi 2 Jenis yaitu static dan dinamic. Iklan game bentuk static terdiri dari elemen yang dikodekan langsung ke dalam game selama pengembangannya, dan yang tidak dapat diubah atau dihapus tanpa versi baru dari game yang dirilis. Mereka adalah metode awal dimana pesan pemasaran muncul dalam game, sedangkan iklan game bentuk dinamic membutuhkan internet sehingga memungkinkan konten iklan diubah, atau untuk tambahan item bermerek yang akan ditambahkan menurut Smith dkk, (2014).

Indonesia ada di peringkat ke 17 dengan pendapatan sebesar Rp15,8 triliun. Potensi periklanan di dalam permainan terbilang sangat berpeluang untuk dilakukan di Indonesia. Perkembangan ini membuat banyak perusahaan internasional maupun nasional melakukan periklanan di dalam game. Periklanan dalam permainan selain menguntungkan bagi para perusahaan pengembang, tetapi juga menaikan kesesuaian terhadap permainan yang nantinya akan berimbas pada minat pembelian dalam Chang dkk, (2010).

Penelitian ini menggunakan permainan balap, permainan balap yang digunakan dalam penelitian ini adalah F1 Mobile Racing. Di dalam game ini terdapat banyak merek seperti : Rolex, DHL, Fly Emirates, dll, namun peneliti tertarik untuk meneliti Rolex dikarenakan brand Rolex yang sudah ternama, dan hampir semua orang mengetahuinya.

Penelitian mengenai In-game advertising sebelumnya pernah dilakukan oleh Chang dkk, (2010) ini berjudul "Online In-Game Advertising Effect: Examining the Influence of a Match Between Games and Advertising." Pada penelitian ini mereka meneliti tentang pengaruh 3 dimensi in-game advertising yaitu congruity, integration, dan prominence terhadap ketertarikan dan minat pembelian, dimana hasil dari penelitian ini ketiga variabel independen tersebut berpengaruh terhadap purchase intention. Selain Chang dkk, penelitian ini juga pernah dilakukan oleh Soebandhi \& Andriansyah, (2017) dengan judul "In-Game Advertising: Analyzing the Effects of Brand Congruity, Integration, and Prominence towards IGA Attitude and Purchase Intention." Hasil penelitian ini ketiga variabel independen tersebut berpengaruh terhadap IGA Attitude namun tidak berpengaruh terhadap purchase intention.

\section{KAJIAN TEORI}

Teori ini menggunakan The limited capacity model of motivated mediated message processing (LC4MP) karena sangat berpengaruh terhadap keberhasilan brand mengiklankan produknya di dalam game. Limited capacity model of motivated mediated message (LC4MP) menunjukkan bahwa kemampuan seseorang untuk memproses informasi itu terbatas, dengan orang hanya memiliki akses terbatas pada waktu tertentu (Lang, 2009).

Selain itu penelitian ini juga menggunakan teori consumer decision dimana Stankevich, (2017) menyatakan bahwa consumer decision making adalah proses dimana setiap individu mencari, menentukan, membeli, memakai, membuang barang dan jasa, dan kepuasaan terhadap barang dan jasa yang mereka dapatkan.

Menurut Lee dan Faber, (2007) LC4MP selain memiliki kaitan dengan in-game advertising, kapasitas konsumen untuk memproses memori dibagi menjadi menjadi kegiatan primer dan sekunder. Ketika kapasitas seseorang digunakan untuk kegiatan primer maka tidak dapat masuk ke kegiatan sekunder. Hal ini selaras dengan game online karena ketika 
bermain game merupakan kegiatan primernya, maka hal sekundernya merupakan segala iklan dalam game.

Bagi banyak produk tahap keputusan pembelian merupakan tahap terakhir dari proses yang panjang dalam proses periklanan. Belch G \& Belch M, (2009) menyatakan bahwa perusahaan harus mengetahui kebutuhan konsumen dan mencoba untuk memberikan kepuasaan sehingga konsumen dapat mencapai ke tahap pembelian. Mereka harus mengetahui darimana konsumen mendapatkan informasi tentang alternatif.

Menurut Celuch and Slama dalam Chang dkk., (2010) congruity adalah kesesuaian antara sumber program dan keterlibatan iklan yang mempengaruhi efektivitas iklan. Adanya kesesuaian iklan di dalam permainan akan membuat konsumen mendapatkan pengalaman yang bagus dalam bermain permainan tersebut. Menurut Heckler \& Childers, dalam Peters and Leshner (2013) congruity adalah hubungan antara visual dan verbal di suatu iklan, kesesuaian yang baik akan membuat tatapan secara visual dan verbal menjadi lebih baik.

Menurut Lewis and Porter dalam Chang dkk, (2010) integration adalah sejauh mana iklan dalam game berhubungan dengan permainan. integration membuat brand untuk sampai ke konsumen dengan cara menyatukan brand ke dalam media hiburan yang digunakan konsumen sebagai sarana hiburan, brand bisa dimasukan ke dalam naskah skrip (film), banner (permainan), dll. Menurut Ghanesh, (2004) integration adalah sebuah sistem integrasi yang mampu meng-handle banyak saluran operasi untuk sebuah perusahaan. Menurut Neslin dkk, (2006) integration adalah keputusan tentang jumlah saluran untuk diadopsi, sifat interaksi di antara mereka dan saluran apa yang akan ditawarkan kepada pelanggan untuk tujuan tertentu.

Minat beli merupakan langkah terakhir dalam proses keputusan yang terjadi kepada konsumen. Menurut Meyers-Lecy \& Maheswaran dalam Lin, (2014) Purchase Intention adalah "sejauh mana periklanan membuat para peserta ingin membeli produk, dan apakah peserta akan mempertimbangkan membeli produk segera atau di masa depan." Menurut Chen dkk., (2010) Purchase Intention digambarkan sebagai "hasrat konsumen untuk melakukan pembelian." Ketika konsumen merasa berminat terhadap produk / jasa tersebut maka konsumen akan membeli produk / jasa tersebut.

Model penelitian pada penelitian ini dapat digambarkan sebagai berikut:

Gambar 1. Model Penelitian

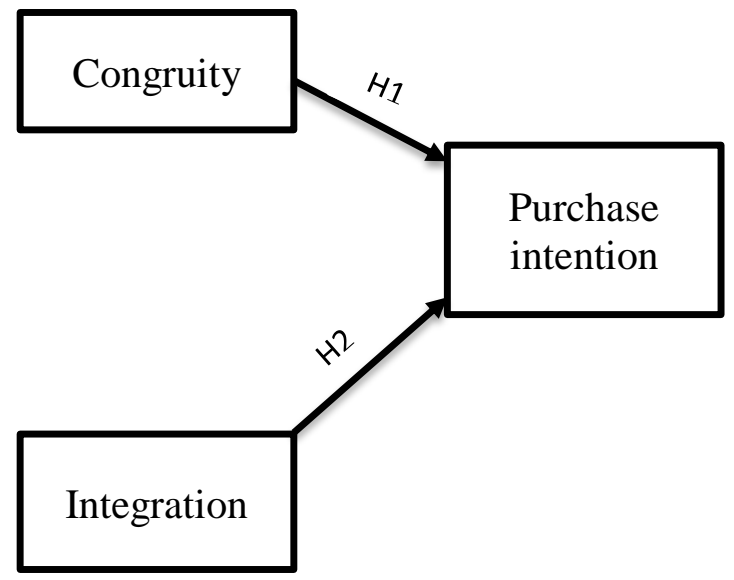


Berdasarkan model penelitian yang telah dipaparkan diatas, maka menghasilkan hipotesis sebagai berikut:

$\mathrm{H}_{1}$ : Congruity (kesesuaian) berpengaruh positif terhadap Purchase Intention (minat beli) $\mathrm{H}_{2}$ : Integration (kesatuan) berpengaruh positif terhadap Purchase Intention (minat beli)

\section{METODOLOGI}

Penelitian ini menggunakan desain penelitian kausal. Penelitian kausal digunakan untuk memahami hubungan antara dua atau lebih variabel. untuk memahami hubungan antara dua atau lebih variabel, Penelitian kausal menjelaskan bagaimana variabel berhubungan. Dalam desain penelitian ini harus dapat menjelaskan mengenai hubungan akan sebab akibat variabel independen dan variabel dependen Sarstedt \& Mooi, (2019).

Populasi adalah kelompok dari unit yang ingin kita buat penilaian. Unit ini dapat berupa kelompok individu, pelanggan, perusahaan, produk, atau hampir semua subjek di mana yang kita tertarik (Sarstedt \& Mooi, 2019). Populasi dalam penelitian ini adalah pengunjung Mall Ciputra dan Mahasiswa Universitas Tarumanagara yang menyadari adanya iklan Rolex setelah bermain game.

Sampel yang diambil dalam penelitian ini adalah 30 responden yang berada di sekitar Universitas Tarumanagara. 15 sampel dalam satu grup sudah dianggap cukup untuk penelitian eksperimen (Creswell, 2012:146)

Cara pengambilan sampling adalah dengan menggunakan orang - orang di sekitar lingkungan Universitas Tarumanagara secara acak sebagai partisipan. Kemudian Peneliti menjelaskan tujuan dan prosedur penelitian pada partisipan. Setelah itu Peneliti memberikan game yang akan dimainkan di smartphone peneliti kepada partisipan. Setelah game dimainkan, peneliti membagikan kuesioner dan mempersilahkan partisipan untuk mengisinya. Setelah partisipan selesai mengisi, peneliti mengambil kembali kuesioner tersebut dari partisipan.

\section{HASIL ANALISIS DATA}

Dalam penelitian ini perlu adanya uji validitas dan reliabilitas terlebih dahulu. Joppe dalam Golafshani (2003) menyatakan validitas menentukan apakah penelitian sesungguhnya mengukur apa yang dimaksudkan untuk diukur atau seberapa jujur hasil penelitiannya. Dalam penelitian ini, uji validitas dapat dilihat dari nilai outer loading, cross loadings, dan average variances exctracted (AVE). Dengan syarat nilai average variances extracted harus diatas 0,5 (Okazaki, 2012). Ketika nilai AVE sudah diatas 0,5 maka indikator dapat diterima. Apabila nilai outer loadings dibawah 0.5 maka dinyatakan tidak layak atau tidak valid. (Ghozali, 2014). Cross loadings dapat dinyatakan lolos uji apabila nilai dari indikator tersebut lebih besar dari indikator lain (Okazaki, 2012).

Nilai AVE dari Masing Masing variabel di atas, dapat dilihat bahwa nilai AVE dari variabel congruity adalah 0.630 , unutk variabel integration adalah 0.638 , dan untuk variabel purchase intention adalah 0.659. Sesuai dengan syarat acuan dimana nilai koefisien harus lebih besar dari 0,5, maka nilai dari AVE sudah memenuhi syarat. Dengan demikian dapat disimpulkan bahwa semua variabel pada penelitian ini telah lolos uji dan memenuhi syarat AVE ( 
Reliability berarti nilai atau skor dari instrumen stabil dan konsisten. Nilai atau Skor harus hampir sama ketika peneliti mengelola instrumen beberapa kali pada waktu yang berbeda. Juga, Skor harus konsisten. Ketika seorang individu menjawab pertanyaan tertentu satu cara, individu hendaknya secara konsisten menjawab pertanyaan yang berhubungan erat dengan cara yang sama (Crewsell, 2012:159). Uji reliabilitas dapat dilihat dari nilai Composite Reliability (CR) dan cronbach's Alpha, dengan syarat nilai CR harus sama atau lebih besar dari 0,7 (Bagozzi and Yi dalam Chang, 2010). Apabila nilai cronbach's alpha sudah > 0,6, maka variabel tersebut dapat dikatakan reliabel dan sudah memenuhi standar cronbach's alpha.

Uji asumsi analisis data dalam penelitian ini menggunakan

1. Uji Multikolinieritas

Menurut Hair dkk (2011) Uji multikolinieritas adalah sebuah pengujian asumsi analisis data yang digunakan untuk menguji antar variabel bebas. Syarat multikolinieritas adalah nilai Variance Inflation Factor (VIF) $<5$. Nilai dari variabel congruity terhadap purchase intention adalah 1.571, dan untuk variabel integration terhadap purchase intention adalah 1.571. Oleh karena itu, tidak terdapat multikolinieritas antara variabel congruity terhadap purchase intention dan variabel integration terhadap purchase intention dikarenakan nilai $\mathrm{VIF}<5$.

2. Uji Relevansi Prediksi $\left(\mathrm{Q}^{2}\right)$

Uji Relevansi Prediksi diukur dengan melihat nilai dari $\mathrm{Q}^{2}$. Uji relevansi prediksi dilakukan dengan prosedur blindfolding. Apabila nilai relevansi prediksi $(\mathrm{Q} 2)>0$ maka model mempunyai relevansi prediktif. Sedangkan jika nilai relevansi prediksi $(\mathrm{Q} 2)<0$ maka model tidak mempunyai relevansi prediktif (Okazaki, 2012). Seluruh nilai Predictive Relevance pada variabel congruity memiliki nilai relevansi prediksi sebesar $0.285(>0)$, yang berarti variabel congruity yang diteliti telah memenuhi syarat relevansi prediksi (Q2). Sedangkan variable integration memiliki nilai relevansi prediksi sebesar 0.295 (> 0), yang dimana variabel integration yang diteliti telah memenuhi syarat relevansi prediksi (Q2). Nilai relevansi prediksi pada variabel purchase intention adalah sebesar $0.406(>0)$, yang berarti variabel purchase intention yang diteliti telah memenuhi syarat relevansi prediksi (Q2).

\section{Uji Koefisien Determinasi $\left(\mathrm{R}^{2}\right)$}

Menurut Henseler et al (2009) dalam Kriteria evaluasi utama untuk model struktural adalah nilai $R^{2}$ dan level serta signifikansi hubungan model struktural. Nilai $R^{2} 0,75,0,50$, atau 0,25 untuk variabel laten endogen dapat dianggap sebagai kuat, moderat, atau lemah. dapat dilihat bahwa nilai $\mathrm{R}^{2}$ dari variabel purchase intention adalah sebesar 0.125. Oleh karena itu variabel purchase intention memiliki pengaruh yang lemah.

\section{Uji Path Coefficients}

Uji path coefficients digunakan untuk menjelaskan hubungan antara variabel exogen dan endogen yang telah dihipotesis. Uji ini dilakukan menggunakan prosedur bootstrapping. besar pengaruh congruity terhadap purchase intention adalah sebesar 0.323 , dan besar pengaruh integration terhadap purchase intention adalah sebesar 0.151 .

Nilai path coefficients dari variabel congruity terhadap purchase intention sebesar 0.323 dengan nilai p value sebesar 0.161 (>0.05). Dengan nilai p value $>0.05$, maka dapat disimpulkan bahwa congruity tidak berpengaruh positf terhadap purchase intention. Nilai path coefficients dari variabel integration terhadap purchase intention sebesar 0.151 dengan 
nilai $\mathrm{p}$ value sebesar 0.556 (>0.05). Dengan nilai $\mathrm{p}$ value $>0.05$, maka dapat disimpulkan bahwa integration tidak berpengaruh positf terhadap purchase intention

\section{DISKUSI}

Penelitian ini mengacu pada teori The Limited capacity model of motivated mediated message processing (LC4MP), yang dimana teori ini menyatakan bahwa kemampuan seseorang untuk memproses informasi itu terbatas, dengan orang hanya memiliki akses terbatas pada waktu tertentu (Lang, 2009). Lebih khusus lagi, model ini menyiratkan bahwa ketika orang jenuh maka rangsangan kemampuan pengolahan mereka (yaitu encoding, menyimpan dan pengambilan informasi) akan berkurang (Lang, 2017; Terlutter \& Capella, 2013).

Keterkaitan antara teori LC4MP dengan penelitian ini adalah dimana teori ini menggambarkan bagaimana informasi yang didapatkan oleh konsumen setelah bermain game ini, apakah informasi yang berupa iklan itu dapat sampai atau tidak. Tidak semua konsumen dapat merasakan adanya iklan di dalam game tersebut. Hal ini lah yang menjadi penguat ada konsumen yang menyadari adanya iklan di dalam game tersebut, ada juga yang tidak menyadari adanya iklan dalam game tersebut. Ketika konsumen merasa congruity di dalam game tersebut baik maka ia akan menyadari iklan tersebut dan mungkin saja tertarik untuk membeli produk atau jasa tersebut. Begitu juga dengan integration, apabila konsumen merasa integration di dalam game tersebut baik maka ia akan menyadari iklan tersebut dan mungkin saja tertarik untuk membeli produk atau jasa tersebut. Di dalam penelitian terdahulu Chang dkk (2010) variabel congruity dan integration berpengaruh positif terhadap purchase intention. Ada beberapa hal yang membuat hasil penelitian ini tidak sesuai dengan penelitian Chang dkk (2010) yang pertama adanya perbedaan cara dalam eksperimen, yang kedua adalah perbedaan jumlah sampel yang cukup besar.

Partisipan pada penelitian ini berusia di antara $20-25$ tahun. Dimana laki - laki sebanyak 30 orang dan perempuan sebanyak 10 orang. Sebagian besar partisipan belum pernah bermain game ini sebelumnya.

\section{KESIMPULAN}

Hipotesis 1 tidak didukung, Congruity tidak berpengaruh positif terhadap Purchase intention. Terkait penelitian sebelumnya dari Chang dkk (2010) hasil ini tidak sejalan dengan penelitian terdahulu. Namun hasil ini sejalan dengan penelitian dari Soebandhi \& Adriansyah (2017) dimana congruity tidak berpengaruh terhadap purchase intention.

Hipotesis 2 tidak didukung, Integration tidak berpengaruh positif terhadap Purchase intention. Terkait penelitian sebelumnya dari Chang dkk (2010) hasil ini tidak sejalan dengan penelitian terdahulu. Namun hasil ini sejalan dengan penelitian dari Soebandhi \& Adriansyah (2017) dimana integration tidak berpengaruh terhadap purchase intention.

Dari peristiwa ini dapat dikatakan bahwa tingginya congruity dan integration tidak memiliki pengaruh terhadap purchase intention dalam game. 


\section{DAFTAR PUSTAKA}

Chang, Y., Yan, J., Zhang, J., \& Luo, J. (2010). Online In-Game Advertising Effect: Examining the Influence of a Match Between Games and Advertising. Journal of Interactive Advertising, 11(1), 63-73.

Ganesh, J. (2004), Managing customer preferences in a multi-channel environment using Web services", International Journal of Retail \& Distribution Management, 32(3), $140-146$

Ghozali, I. (2014) Structural Equation Modeling - Metode Alternatif dengan Partial Least Squares (PLS). Semarang: Universitas Diponegoro.

Henseler, J., Ringle, C., and Sinkovics, R. (2009). The use of partial least squares path modeling in international marketing. Advances in International Marketing (AIM), 20, 277-320.

Herhausen, D., Binder, J., Schoegel, M., \& Herrmann, A. (2015). Integrating bricks with clicks: retailer-level and channel-level outcomes of online-offline channel integration. Journal of retailing, 91(2), 309-325.

Herrewijn , L. (2015). The Effectiveness of In-Game Advertising: The Role of Ad Format, Game Context and Player Involvement.

Jagre, E., Watson, J. J., \& Watson, G. J. (2001). Sponsorship and Congruity Theory: a Theoretical Framework For Explaining Consumer Attitude and Recall of Event Sponsorship, 28, 439-445.

Lang, A. (2017). Limited Capacity Model of Motivated Mediated Message Processing (LC4MP). The International Encyclopedia of Media Effects., 19.

Lee, Mira, and Ronald J. Faber (2007), "Effects of Product Placement inOn-Line Games on Brand Memory: A Perspective of the Limited-Capacity Model of Attention," Journal of Advertising, 36 (4), 75-90.

Lewis, B., \& Porter, L. (2010). In-Game Advertising Effects. Journal of Interactive Advertising, 10(2), 46-60.

Malhotra, N. K. (2010). Marketing Research: An Applied Orientation. New Jersey: Pearson.

Maulida, L. (2018, Oktober 17). Jumlah gamer di Indonesia capai 100 juta di 2020. Retrieved from tek.id: https://www.tek.id/insight/jumlah-gamer-diindonesia-capai-100-jutadi-2020-b1U7v9c4A

Neslin, S. A., Grewal, D., Leghorn, R., Shankar, V., Teerling, M. L., Thomas, J. S., \& Verhoef, P. C. (2006). Challenges and Opportunities in Multichannel Customer Management, Journal of Service Research, 9(2), 95-112

Okazaki, S. (2012). Handbook of Research on International Advertising, Cheltendam: Edward Edgard.

Peters, S., \& Leshner, G. (2013). Get in the Game: The Effects of Game-Product Congruity and Product Placement Proximity on Game Players' Processing of Brands Embedded in Advergames, Journal of Advertising, 42(2-3), 113-130.

Sarstedt, M., \& Mooi, E. (2019). A Concise Guide to Market Research. Berlin: Springer.

Semuel, H., \& Lianto, A. S. (2014). Analisis Ewom, Brand Image, Brand Trust dan Minat Beli produk smarthpone di Surabaya. Jurnal Manajemen Pemasaran, 8(2), 47-54.

Smith, M. W., Sun, W., Sutherland, J., \& Mackie, B. (2014). Game advertising: a conceptual framework and exploration of advertising prevalence. The Computer Games Joumal, 3(1), 95-124. 
Soebandhi, S., \& Adriansyah, Y. (2017). In-Game Advertising: Analyzing the Effects of Brand Congruity, Integration, and Prominence towards IGA Attitude and Purchase Intention. Jurnal Manajemen Teknologi , 258-270.

Stankevich, A. (2017). Explaining the Consumer Decision-Making Process: Critical Literature Review. Journal of International Business Research and Marketing, 2(6), 7-13.

Wang, X., Yang, Z., \& Liu, N. R. (2009). The impacts of brand personality and congruity on purchase intention: Evidence from the Chinese mainland's automobile market. Journal of Global Marketing, 22(3), 199-215.

Yang, M., Ewoldsen, D. R., Dinu, L., \& Arpan, L. M. (2006). THE EFFECTIVENESS OF "IN-GAME" ADVERTISING. Journal of Advertising, 35(4), 143-152.

Younus, S., Rasheed, F., \& Zia, A., (2015). Identifying the Factors Affecting Customer Purchase Intention. Global Journal of Management and Business Research: A Administration and Management, 15(2), 8-14. 